УДК 614.083:616.093.75

DOI 10.11603/2411-1597.2021.2.12289

\title{
ДЕОНТОЛОГІЧНІ ПРИНЦИПИ ТА ПСИХОЛОГІЧНІ ОСОБЛИВОСТІ ПРОФЕСІЙНОЇ ВЗАЄМОДІЇ МЕДИЧНИХ СЕСТЕР І ПАЦІЄНТІВ
}

\author{
Є. В. Тишкевич-Львова \\ Тернопільський національний медичний університет \\ імені І. Я. Горбачевського МОЗ Украӥни \\ ННІ медсестринства
}

\begin{abstract}
У статті розглянуто деонтологічні принципи та психологічні особливості професійної взаємодії медичних сестер і пацієнтів. Встановлено, що ефективність взаємодії медичних сестер із пацієнтами залежить від їх уміння встановлювати контакт із ними. У своїй професійній діяльності медичні сестри повинні дотримуватися деонтологічних правил, які є основою різних моделей взаємодії медсестер та пацієнтів (уважний догляд за хворими, «не нашкодь», здатність швидко приймати рішення у складних ситуаціях, добросовісність у виконанні професійних обов'язків). Окреслено існуючі моделі взаємодії медичних сестер і пацієнтів (керівництво, партнерство, контрактна, інженерна, патерналістська, колегіальна).
\end{abstract}

\section{DEONTHOLOGICAL PRINCIPLES AND PSYCHOLOGICAL FEATURES OF PROFESSIONAL INTERACTION OF NURSES AND PATIENTS}

\author{
Ye. V. Tyshkevich-Lvova

\section{Horbachevsky Ternopil National Medical University Institute of Nursing}

\begin{abstract}
The article considers deontological principles and psychological features of professional interaction of nurses and patients. It has been established that the effectiveness of the nurse's interaction with the patient depends on her ability to establish contact with the patient. In professional activity, the nurse must adhere to the deontological rules that are the basis of various models of interaction between nurses and patients (careful care of the patient, "do no harm», ability to make quick decisions in difficult situations, conscientiousness in the performance of professional duties). The existing models of interaction between the nurse and the patient (leadership, partnership, contract, engineering, paternalistic, collegial) are outlined.
\end{abstract}

Вступ. Будь-яка професійна діяльність з людьми нерозривно пов'язана з процесом і проблемами спілкування. Спілкування пронизує професійну діяльність медичних працівників на будь-якому рівні. Індивідуальні особливості психіки пацієнтів за умов лікувальної взаємодії поєднуються з психологічними властивостями медичних працівників. Метою такого контакту $є$ допомога пацієнтам. У такій взаємодії зацікавлені, водночас, пацієнти і медичні працівники, діяльність яких зумовлена мотивами й інтересами ефективної взаємодії з пацієнтами, що регламентовано їх професійним покликанням.

Зростання ролі медичних працівників як активних виконавців лікувальних процедур у медико-профілактичній діяльності стимулює пошук нових підходів до оцінки рівня розвитку їхніх особистісних якостей,

(с) Є. В. Тишкевич-Львова, 2021 дослідження тих із них, які зумовлюють успішність професійної діяльності.

Основна частина. Взаємини між медичними сестрами і пацієнтами є наслідком загальнолюдських відносин, основаних на принципах гуманізму та співчуття. Регулювання таких відносин у діаді «медична сестра - пацієнт» забезпечується дотриманням певних етичних принципів медичної деонтології. Водночас передумови взаємодії медичних сестер і пацієнтів формуються з урахуванням низки чинників, зумовлених очікуваннями пацієнтів:

1) попередня інформація про медсестру (апріорна думка, сформована під впливом свідків, отримана від інших хворих і/або медпрацівників);

2) репутація медичного закладу (наприклад його престижність); 
3) «дорога» до медичного закладу (рівень «доступності», наприклад попередній запис, тривалість очікування прийому: чим важче потрапити, тим більше задоволення від досягнутого) [3].

Успішність діяльності медичних сестер значною мірою залежить від їх якості комунікативної взаємодії, тому вміння вислухати, заспокоїти, надати пораду, стати співучасниками певної стратегії поведінки $\epsilon$ покликанням медсестер. Для ефективної й безконфліктної взаємодії з пацієнтами для медичних сестер важливою є сформованість комунікативної компетентності - здатності встановлювати і підтримувати необхідні контакти з людьми для досягнення взаєморозуміння між партнерами спілкування, усвідомлення ситуації та предмета спілкування. Досліджуючи особливості професійної взаємодії медичних працівників і пацієнтів, С. Поплавська розглядає комунікативну компетентність як систему внутрішніх ресурсів, спрямованих на побудову ефективної комунікації в ситуації міжособистісної взаємодії, оскільки, на думку дослідниці, некомпетентність в спілкуванні здатна погіршити діагностичний і лікувальний процеси [4].

Етичні засади професійної комунікації медичних працівників регламентовані низкою вітчизняних та ратифікованих міжнародних нормативно-правових документів (Основи законодавства України про охорону здоров'я, Етичний кодекс медичної сестри України, Міжнародний кодекс медичної етики, Міжнародна клятва лікарів, Постанова Комітету міністрів Ради Європи «Пропозиції державам-учасницям для покращення розподілу медичної допомоги в лікарнях і поза лікарнями», Гельсінська декларація «Рекомендації для лікарів, які проводять біологічні обстеження людини», Міжнародне положення про медичне обстеження, телемедицину та медичну етику).

Вивчення можливостей дотримання вимог професійної етики в сучасних умовах $є$ однією з проблем педагогіки. Так, ведучи пошук можливих шляхів виховання гуманності у студентів медичного коледжу в процесі фахової підготовки, О. Андрійчук виокремлює характеристики медпрацівників, які забезпечують успішне спілкування з пацієнтами:

1) емпатія (усвідомлене співпереживання емоційному стану);

2) акцептація (безумовне позитивне прийняття хворого);
3) автентичність або самоконгруентність (природність поведінки, узгодженість почуттів та їх вираження, щирість) [1].

Ефективність взаємодії медичних сестер із пацієнтами залежить від їх уміння встановлювати контакт із ними, у процесі якого пацієнти переконуються у можливості використання власних внутрішніх резервів для успішної боротьби з хворобою, від здатності створювати довірливий клімат, проявляючи щирість, створюючи атмосферу взаємодовіри, враховуючи очікування пацієнтів від процесу діагностики, лікування й реабілітації. У своїй професійній діяльності медичні сестри повинні дотримуватися деонтологічних правил, які є основою різних моделей взаємодії медсестер та пацієнтів (уважний догляд за хворими, «не нашкодь», здатність швидко приймати рішення у складних ситуаціях, добросовісність у виконанні професійних обов'язків).

3 огляду на це, сьогодні комунікативні ролі медичних сестер набувають іншого значення, оскільки вони проводять з пацієнтами більше часу, а їх діяльність пов'язана не лише з сильними фізичними навантаженнями, але й великим емоційним напруженням. Тому доцільно окреслити існуючі моделі взаємодії медсестер і пацієнтів [1, 5]:

1) керівництво - авторитарна модель, яка характеризується пасивною роллю пацієнта в лікувальному процесі, нерівній позиції стосовно лікаря. Медсестри керуються власними професійними знаннями, уявленнями про необхідні лікувальні заходи;

2) партнерство - співпраця щодо питань лікування, яка супроводжується розподілом відповідальності за результати діагностики та лікування між медперсоналом і пацієнтом;

3) контрактна - співпраця на основі взаємних зобов'язань, визначених завдань, очікуваних результатів; така модель застосовується за умов платної медицини, коли обсяг обстежень і лікування визначається запитами пацієнтів.

Важливими у межах дослідження $є$ наукові пошуки американського біоетика Р. Вітча [2], який виокремлює чотири моделі взаємин «медичний працівник - пацієнт», характерні для сучасної культури:

1) інженерна - в межах якої пацієнт розглядається медсестрою як безособовий механізм, а її основним завданням $є$ усунення відхилень у несправному фізіологічному механізмі. Основним недоліком цього типу взаємин є технократичний підхід до пацієнта, 
який суперечить принципу поваги прав і гідності особистості, адже пацієнт не бере участі в обговоренні процесу лікування. Прикладом такої моделі взаємин є хірургічний конвеєр в офтальмологічній клініці Святослава Федорова;

2) патерналістська, в якій міжособистісні відносини подібні до відносин священика і прихожанина або батька та дитини, наставника і підопічного. Принципами ставлення до пацієнтів $є$ любов, милосердя, турбота, доброзичливість і справедливість. У сучасній медицині така модель $є$ найпоширенішою, а найприйнятнішою $є$ в педіатрії, психіатрії, геріатрії. Недоліком моделі $\epsilon$ те, що взаємовідносини можуть перерости у відносини типу «начальник підлеглий»;

3) колегіальна, в межах якої панує принцип рівноправності. Пацієнтам медичні працівники повідомляють правдиву інформацію про діагноз, методи лікування, можливі ускладнення і наслідки захворювання; вони беруть участь в обговоренні цієї інформації. Така гармонія у відносинах між медсестрами і пацієнтами передусім $\epsilon$ винятком з правил, а ефективність колегіальної моделі доведена у роботі з пацієнтами з хронічними захворюваннями;

4) контрактна - здійснюється на принципах суспільного договору (пацієнти укладають договір на

\section{СПИСОК ЛІТЕРАТУРИ}

1. Андрійчук О. Я. Виховання гуманності у студентів медичного коледжу в процесі фахової підготовки : автореф. дис. на здобуття наук. ступеня канд. пед. наук : спец. 13.00.07 «Теорія та методика виховання» / О. Я. Андрійчук. - К., 2003. - 19 с.

2. Витч Р. Модели взаимоотношения «врач - пациент» [Электронный ресурс] / Роберт Витч. - Режим доступа : http://videoinet.ru/view?id=ISW2tSZDvVsS931.

3. Назар П. С. Основи медичної етики / П. С. Назар, Ю. Г. Віленський, О. А. Грандо. - К. : Здоров'я, 2002. - 344 с. медичне обслуговування з лікувальним закладом або страховою компанією. У такому договорі кожна сторона несе свої зобов'язання і досягає своєї вигоди). Контрактна модель покликана захистити моральні цінності особистості, проте в структурі надання медичної допомоги населенню займає незначне місце.

Висновки. Розглянуті моделі взаємин є ідеальними конструкціями, а реальний вибір типу відносин визначається психологічними особливостями медсестри, конкретною ситуацією стану хворого, характером медичної допомоги. Отже, варто узагальнити, що медсестринська діяльність, як й усі професії типу «людина - людина», передбачає наявність обов'язкового компонента - спілкування, оскільки на всіх етапах медичної практики відбувається безпосередній контакт із пацієнтами: діагностика, консультації, лікування або профілактичні дії. Спілкуючись із хворими, медсестри вислуховують скарги пацієнтів на своє здоров'я й самопочуття, спостерігають за станом хворих у процесі лікування, враховують визначені лікарем об'єктивні ознаки захворювання. Тому опора в їх діяльності на деонтологічні принципи відіграє ключову роль у забезпеченні ефективності майбутньої медсестринської діяльності.

4. Поплавська С. Д. Етика професійної взаємодії медпрацівника і хворого / С. Д. Поплавська // Комп'ютерноінтегровані технології : освіта, наука, виробництво. 2013. - № 11. - С. 121-127.

5. Романюк Л. В. Ціннісні орієнтації студентів : сутність, структура і психологічні механізми розвитку : навч. посіб. / Л. В. Романюк ; за заг. ред. Ю. Г. Кондратюка. Кам'янець-Подільський : Абетка-Нова, 2004. - 188 с.

Отримано 19.04.21 